HORTSCIENCE 28(9):937-938. 1993.

\section{Estimating Phenylalanine Ammonia- lyase Activity in Common Beans Inoculated with Sclerotinia sclerotiorum}

\author{
Phillip N. Miklas ${ }^{1}$ \\ Tropical Agricultural Research Station, Agricultural Research Service, U.S. \\ Department of Agriculture, P.O. Box 70, Mayaguez, PR 00681
}

Kenneth F. Grafton ${ }^{2}$ and Phillip E. McClean ${ }^{2}$

Department of Crop and Weed Sciences, North Dakota State University, Fargo, ND 58105-5051

Additional index words. white mold, Phaseolus vulgaris, plant defense enzyme, partial physiological resistance

\begin{abstract}
We investigated the partial physiological resistance (PPR) of common beans (Phaseolus vulgaris L.) to white mold disease caused by Sclerotinia sclerotiorum (Lib.) deBary. The activity of phenylalanine ammonia-lyase (PAL) was measured in detached stems inoculated with a growing mycelium of the pathogen. Noninoculated detached stems and whole plants were included as controls. Five bean cultivars-Upland, Bunsi, Sierra, UI-114, and Montcalm-and one breeding line-NY 5394-were tested; all varied in PPR to white mold disease. Greater PAL activity in the resistant NY 5394 than in the susceptible 'Upland' suggests that PAL activity may be involved in the PPR of common beans to $S$. sclerotiorum.
\end{abstract}

Partial physiological resistance (PPR) to white mold disease caused by Sclerotinia sclerotiorum has been observed in common bean (Miklas et al., 1992a, 1992b). Studies have shown white mold disease to be a quantitatively inherited, polygenic trait (Miklas and Grafton, 1992). To gain insight into this

Received for publication 9 Sept. 1992. Accepted for publication 22 Apr. 1993. Contribution of the North Dakota State Agricultural Experiment Station, paper no. 2085, and the U.S. Dept. of Agriculture (USDA), Agricultural Research Service. Mention of a proprietary product does not constitute a guarantee or warranty of the product by the USDA and does not imply its approval to the exclusion of other products that also may be suitable. The cost of publishing this paper was defrayed in part by the payment of page charges. Under postal regulations, this paper therefore must be hereby marked advertisement solely to indicate this fact.

'Research Geneticist.

${ }^{2}$ Associate Professor.
PPR and quantitative host-pathogen relationships in general, the activity of a plant defenserelated enzyme-phenylalanine ammonialyase (PAL)-was characterized for five common bean cultivars and one breeding line, all varying in PPR to S. sclerotiorum.

The detached stems of white mold-susceptible (S) 'Upland' and partially resistant (PR) 'Bunsi' (known as 'Ex-Rico 23' in Canada) navy beans, S 'UI-114' and PR 'Sierra' pinto beans, PR 'Montcalm' kidney bean, and PR snap bean breeding line NY 5394 were inoculated with a growing S. sclerotiorum mycelium and assayed for PAL activity. Detachment, preparation, inoculation, and subsequent incubation of the main stems were based on procedures described by Miklas et al. (1992a). Briefly, main stems were detached from 28 day-old greenhouse-grown plants. The main stem, including the hypocotyl, of an individual plant was trimmed at the potting soil surface and just below the unifoliate (second) leaf node. These main stem sections were inoculated with $S$. sclerotiorum within $5 \mathrm{~min}$ of their excision. A $3 \times 5-\mathrm{mm}$ piece of tissuepaper inoculum containing a growing mycelium was placed on the newly formed cut surface of the excision made below the second node. A pathogenic isolate, ND26 (from Berlin Nelson, North Dakota State Univ.), was used for all inoculations.

Inoculated stems were placed on trays of moistenedvermiculite. The trays were wrapped with clear plastic to maintain humidity and incubated in darkness on a laboratory bench at ambient room temperature (20C) for $84 \mathrm{~h}$. About 20 inoculated and 20 noninoculated main stem sections from 40 individual plants of each bean type were placed on a tray. One tray from each bean type was evaluated for one greenhouse planting and represented one replication. Four greenhouse plantings were conducted from Oct. to Dec. 1990. The design was a randomized complete block with four replications.

Tissue samples from inoculated and noninoculated stems of each bean type and replication were assayed for enzyme activity. After incubation, samples ( $1 \mathrm{~cm}$ long) were taken from the noninfected tissue at the leading edge (within $1 \mathrm{~mm}$ ) of a lesion or from the middle of a noninoculated stem until enough individual stems were sampled to collect $1 \mathrm{~g}$ (fresh weight) for each treatment. The 1-g samples were frozen with liquid $\mathrm{N}$ and ground immediately using a mortar and pestle. The ground tissue was homogenized with a homogenizer (Polytron; Brinkmann, Westbury, N.Y.) for $15 \mathrm{sec}$ at medium speed in $15 \mathrm{ml}$ extraction buffer $[0.1 \mathrm{M}$ sodium borate $(\mathrm{pH}$ 8.8) plus $2 \mathrm{~mm} 2$-mercaptoethanol and $3 \mathrm{~mm}$ ethylenediatetraacetic acid (EDTA)] (Southerton and Deverall, 1990). The homogenate was centrifuged at $13,000 \times \mathrm{g}$ for $15 \mathrm{~min}$. The bean stem extract (supematant) was brought to 95\% saturation with ammonium sulfate to precipitate protein and reduce background interference by trans -cinnamate (Bolwell et al., 1986).

One milliliter of the ammonium sulfate extract was centrifuged at $14,000 \times \mathrm{g}$ for 10 min. The protein pellet was redissolved in $1 \mathrm{ml}$ extraction buffer and is referred to as the sample extract. The reaction mixture $(2.25 \mathrm{ml})$ 
contained $250 \mu \mathrm{l}$ sample extract, $1.0 \mathrm{ml}$ extraction buffer, and $1 \mathrm{ml} 50 \mathrm{~mm} \mathrm{~L}$-phenylalanine (substrate) in the same buffer (Hughes and Dickerson, 1989). The reaction mixtures were incubated at $37 \mathrm{C}$ in a water bath for $3 \mathrm{~h}$. The concentration of trans -cinnamic acid (product) was determined spectrophotometrically at 290nm (Hughes and Dickerson, 1989). Blanks that contained only buffer were included. PAL specific activity is expressed as nanomoles of trans -cinnamic acid formed per minute per milligram of protein. Protein concentration was determined according to Bradford (1976) using bovine IgG as a protein standard.

An unbalanced analysis of variance of PAL activity was conducted because some bean types were not present in all four greenhouse plantings. SAS Institute's (Cary, N.C.) GLM procedure was used to perform the analysis. Reported means were least-squares-adjusted and separated with an $\mathrm{F}$ test protected least significant difference $(\mathrm{P} \leq 0.05)$ based on smallest $\mathrm{N}$. The noninoculated treatment was not analyzed statistically because no PAL activity was detected.

Lesions (discolored, water-soaked tissue) began at the inoculated stem apex and grew toward the detached stem base as a column, consuming all tissue in its path. Lesion growth was characterized visually after incubation (Table 1). Short lesions were characterized as slow growing and long lesions as fast growing. Lesions formed only in stems that were inoculated with the pathogen mycelium. After incubation, the water-soaked lesions spread further in 'Upland' and 'UI-114' (S) than in 'Bunsi', 'Sierra', 'Montcalm', and NY 5394 (PR). Lesion growth was fastest in 'UI-114' and least in NY 5394 and 'Montcalm'. Lesion growth in 'Bunsi' and 'Sierra' was intermediate. These observations concurred with lesion-length measurements obtained in a previous excised-stem assay (Miklas et al., 1992a).

No PAL activity was detected for any bean type in the noninoculated detached stems. There was a bean type effect for the increased PAL activity among the inoculated detached stems (Table 1). PAL activity increased most in 'Montcalm' and NY 5394 and increased
Table 1. Average phenylalanine ammonia-lyase (PAL) activity for inoculated detached stems of five common bean cultivars and one line inoculated with Sclerotinia sclerotiorum.

\begin{tabular}{llcc}
\hline \hline $\begin{array}{l}\text { Cultivar } \\
\text { or line }\end{array}$ & Class & $\begin{array}{c}\text { Lesion } \\
\text { growth }^{\mathrm{z}}\end{array}$ & $\begin{array}{c}\text { PAL } \\
\text { activity }^{\mathrm{y}}\end{array}$ \\
\hline Upland & Navy & $\mathrm{F}$ & $4.5 \mathrm{a}^{\mathrm{x}}$ \\
Bunsi & Navy & $\mathrm{I}$ & $9.3 \mathrm{ab}$ \\
Sierra & Pinto & $\mathrm{I}$ & $8.3 \mathrm{ab}$ \\
UI-114 & Pinto & $\mathrm{F}$ & $11.0 \mathrm{~b}$ \\
Montcalm & Kidney & $\mathrm{S}$ & $15.5 \mathrm{bc}$ \\
NY 5394 & Snap & $\mathrm{S}$ & $18.5 \mathrm{c}$ \\
Column mean & & & 11.2 \\
\hline
\end{tabular}

${ }^{2} \mathrm{~F}=$ fast (long lesions), $\mathrm{I}=$ intermediate, $\mathrm{S}=$ slow (short lesions).

YPAL is expressed as nanomoles of trans-cinnamic acid formed per minute per milligram of protein.

${ }^{x}$ Mean separation by LSD at $P \leq 0.05$.

least in 'Upland'. 'UI-114' had fast growing lesions; therefore, tissue samples were obtained near the root end of the hypocotyl, a procedure that may have biased its PAL activity upward. This bias is suggested by Rahe and Arnold (1975), who observed that more phytoalexin accumulated toward the root end of common bean hypocotyls.

PAL activity data, when combined with field observations of reddish-brown borders surrounding arrested lesions on 'Montcalm' and NY 5394 (Miklas et al., 1992a), suggest that phenylpropanoid end-products, especially phytoalexins, are components likely to contribute to the PPR of common beans to S. sclerotiorum. This supposition is supported by previous studies that showed that more phytoalexin accumulated in hypocotyls of beans and soybeans [Glycine max (L.) Merr.] that developed limited lesions in response to $S$. sclerotiorum (Sutton and Deverall, 1984), and that oxalic acid and polygalacturonases synthesized by S. sclerotiorum elicited phytoalexin biosynthesis in soybean (Favaron et al., 1988). An increase in PAL activity, however, does not always ensure increased phytoalexin accumulation (Ebel et al., 1984); nonetheless, greater PAL activity paralleled slower lesion growth in this study.

Perhaps the increased PAL activity in response to S. sclerotiorum noted in this study is a result of gene influence on common bean PPR through phytoalexin biosynthesis.

\section{Literature Cited}

Bolwell, G.P., C.L. Cramer, C.J. Lamb, W. Schuch, and R.A. Dixon. 1986. L-Phenylalanine ammonia-lyase from Phaseolus vulgaris: Modulation of the levels of active enzyme by trans-cinnamic acid. Planta 169:97-107.

Bradford, M.M. 1976. A rapid and sensitive method for the quantitation of microgram quantities of protein utilizing the principle of protein-dye binding. Anal. Biochem. 72:248-254.

Ebel, J., W.E. Schmidt, and R. Loyal. 1984. Phytoalexin synthesis in soybean cell: Elicitor induction of phenylalanine ammonia-lyase and chalcone synthase mRNAs and correlation with phytoalexin accumulation. Arch. Biochem. \& Biophys. 232:240-248.

Favaron, F., P. Alghisi, P. Marciano, and P. Magros. 1988. Polygalacturonase isoenzymes andoxalic acid produced by Sclerotinia sclerotiorum in soybean hypocotyls as elicitors of glyceollin. Physiol. Mol. Plant Pathol. 33:385-395.

Hughes, R.K. and A.G. Dickerson. 1989. The effect of ethylene on phenylalanine ammonia lyase (PAL) induction by a fungal elicitor in Phaseolus vulgaris. Physiol. Mol. Plant Pathol. 34:361378.

Miklas, P.N. and K.F. Grafton. 1992. Inheritance of partial resistance to white mold in inbred populations of dry bean. Crop Sci. 32:943-948.

Miklas, P.N., K.F. Grafton, and B.D .Nelson. 1992a. Screening for partial physiological resistance to white mold in dry bean using excised stems. J. Amer. Soc. Hort. Sci. 117:321-327.

Miklas, P.N., K.F. Grafton, G.A. Secor, and P.E. McClean. 1992b. Use of pathogen filtrate to differentiate physiological resistance of dry bean to white mold disease. Crop Sci. 32:310-312.

Rahe, J.E. and R.M. Arnold. 1975. Injury-related phaseollin accumulation in Phaseolus vulgaris and its implications with regard to specificity of host-parasite interaction. Can. J. Bot. 55:921928.

Southerton, S.G. and B.J. Deverall. 1990. Changes in phenylalanine ammonia-lyase and peroxidase activities in wheat cultivars expressing resistance to the leaf-rust fungus. Plant Pathol. 39:223-230.

Sutton, D.C. and B.J. Deverall. 1984. Phytoalexin accumulation during infection of bean and soybean by ascospores and mycelium of Sclerotinia sclerotiorum. Plant Pathol. 33:377-383. 